IJMS 27(2), 47-76(2020)

How to cite this article:

Rusli, M. N., Mohd Saleh, N., Hassan, M. S., \& Hafizuddin-Syah, B. A. M. (2020). The effect of political connections on forward-looking information disclosure from the perspective of the stakeholder salience theory. International Journal of Management Studies, 27(2) July 47-76. https://doi.org/10.32890/ijms. 27.2.2020.9646

\title{
THE EFFECT OF POLITICAL CONNECTIONS ON FORWARD- LOOKING INFORMATION DISCLOSURE FROM THE PERSPECTIVE OF THE STAKEHOLDER SALIENCE THEORY
}

\author{
MAS NORDIANA RUSLI \\ Commerce Department \\ Politeknik Mukah, Sarawak \\ *NORMAN MOHD. SALEH \\ MOHAMAT SABRI HASSAN \\ MOHD HAFIZUDDIN SYAH BANGAAN ABDULLAH \\ Faculty of Economics and Management \\ Universiti Kebangsaan Malaysia \\ Corresponding author: norman@ukm.edu.my
}

\begin{abstract}
This study examines the effect of political connections (PCONS) on firms' disclosure of forward-looking information choices in the context of developing countries. Using multivariate regression of panel data comprising 360 firmyear observations of non-financial firms listed on Bursa Malaysia between years 2014 and 2017, PCONS are found to be positively associated with disclosure of forward-looking information. However, such relationship only exists for non-financial forward-looking information. Using the stakeholder salience theory to further contribute to the body of knowledge, the strength of the connections suggests that a high composition of politically-connected directors on the board promotes greater information about the future in firms' disclosure. The common connection through ownership of firms in
\end{abstract}


emerging countries suggests the effective role of institutional shareholders in improving forecasting activities through high disclosure of forward-looking information. The study suggests a better appreciation of the hierarchical role of politically-connected directors on the board of types of forward-looking information presented to the stakeholders.

Keywords: political connections, forward-looking information, information asymmetry, political power, voluntary disclosure.

Received: 29/12/2019 Revised: 10/07/2020 Accepted: 15/07/2020 Published: 11/10/2020

\section{Introduction}

Politicians have pervasive influence on businesses by assuming positions of CEOs, chairpersons of the board or board members to induce investments among firms around the world (Boubakri, Cosset, \& Saffar, 2008; Rusli, Mohd Saleh, Sabri Hassan, \& Hafizuddin-Syah, 2019). The dominant effects of the helping hand (positive effects) over the grabbing hand (negative effects), as suggested under the political hypothesis, have increased the firms' demand for political connections $(P C O N S)$, especially in developing economies. Prior literature has shown that political connections affect firm performance, financial decisions (through debt and equity) and transparency, i.e., disclosure of information (for example, Ball, Robin, \& Wu, 2003). However, not much is understood on the impact of the strength and types of political connections on a firm's disclosure behaviour. As such, the objective of this study is to investigate the effect of the strength of political connections and its types on a very specific type of information disclosure, namely, forward-looking (financial and non-financial) information disclosure. In this study, we attempt to answer the question: Do the strength and types of political connections influence the level and types of forward-looking information disclosure?

Forward-looking information disclosure refers to current plans and future forecasts that enable investors and other users to assess or predict a firm's future financial performance (Aljifri \& Hussainey, 2007). The information disclosed is both financial and non-financial, including next year's earnings, expected revenues, anticipated cash flows, risks and uncertainties. The discussion is about firms' risks 
and opportunities, strategic planning and future projects from the viewpoint of managers. This information is important for investors to make informed investment decisions. Forward-looking information disclosure may also improve the efficiency of the capital market (Bravo, 2016). However, the amount and quality of the information provided depends on the management and boards of the firms.

When politicians control a firm either through a representative on the board or the management or through the ownership of shares, beneficial forward-looking information is provided in exchange. Firstly, this argument is based on the nature of forward-looking politicians who are very much involved in policy making and foreseeing the future. Moreover, political directors have also been found to be prone to providing unique information about public policy, which is often very expensive or difficult for a firm to obtain (Hillman, Cannella, \& Paetzold, 2000). Secondly, politicians who have information about the government's long-term plans may align the firm's plans with those of the government, thus providing disclosure to secure the firm's future direction (Rusli et al., 2019). However, not much can be learnt from the literature about the link between political connections and firms' forward-looking information disclosure.

We derive the argument of this study from the stakeholder salience theory, i.e., the higher the position of a political director/manager in the government, the more the influence (in terms of power, legitimacy or urgency) the director/manager has on the firm's forward-looking information disclosure. This expectation is similar to that of Huang and Zhao (2016) and Du and Xiu (2009). We also examine the types of connections to determine the level of disclosure of forward-looking information. We believe that the capacity of a political position in the political system may cause variations in the firms' disclosure behaviour.

This study makes several important contributions. Firstly, prior literature has mostly examined the effect of political connections on a firm's performance (Huang \& Xiao, 2012; Jaffar \& Abdul-Shukor, 2016; Faccio, 2006); advantages for listing (Francis, Hasan, \& Sun, 2009); corporate social responsibility (Huang \& Zhao, 2016); and corporate voluntary disclosure (Hung, Kim, \& Li, 2018). Although politicians are naturally visionary, the examination of political connections in 
relation to forward-looking information disclosure is still lacking. Secondly, unlike most prior studies that have used dichotomy, i.e., existence versus non-existence of political influence, this study brings in the richness of the hierarchy within the governmental structure using the stakeholder salience theory. The argument has been used by Huang and Zhao (2016) in the context of Chinese corporate social responsibility. We use two proxies to determine the strength of political connections as suggested by Tsai, Zhang and Zhao (2019) and Francis et al. (2009). We choose Malaysian firms that are known to be politically-connected or favoured as the sample of the study (Abdul Wahab \& Abdul Rahman, 2009; Gomez \& Jomo, 1999; Gul, 2006; Johnson \& Mitton, 2003). Hence, this study attempts to fill the gap on the impact of political connections on the level of information disclosure in the context of a developing country.

To achieve our objective and to answer the research question, we consider non-financial listed firms on the Main Board of Bursa Malaysia across industries for a four-year period from 2014 to 2017. We adopt a method suggested by Abed and Al-Najjar (2016) that uses text-unit analysis to gather forward-looking information from firms' annual reports. The independent variable for each political connection is defined following prior literature (Bliss \& Gul, 2012; Boubakri et al., 2008; Fung, Gul and Radhakrishnan (2015), 2015; Faccio, 2006; Rusli et al., 2019), and coded as dummy variables (CONNECT and TYPES), whereby strength is measured as a continuous variable. Our findings show that the disclosure level of forward-looking information is high among politically-connected firms. The positive association between political connection and such disclosure level is more significant among firms connected through ownership than directorship. However, the disclosure of forward-looking information is only significant for nonfinancial forward-looking types. We suggest that government stakes through ownership is more efficient in influencing non-financial forward-looking information than individual politicians. Therefore, the study expects to provide practical implications in terms of understanding the effect of a political director's hierarchy within the board or management on the types of forward-looking information disclosure presented to stakeholders. The benefits of high disclosure of forward-looking information also leans on the agency framework. The roles of political directors in reducing the agency cost of the firm through disclosure may result in high disclosure of forward-looking information. 
The remainder of the paper is structured as follows: literature review on forward-looking information disclosure and hypothesis development, research design and findings and conclusion.

\section{Literature Review and Hypotheses Development}

The literature on political economy has shown that political connections have a favourable impact on connected firms. The benefits enjoyed by such connected firms, both monetary and non-monetary, can be found worldwide. Under the monetary effects, connected firms have been found to enjoy lower interest rates on credit facilities and lower costs in financing. Likewise, non-monetary benefits arise from lucrative government projects (Agrawal \& Knoeber, 2001; Goldman, Rocholl, \& So, 2009; Gomez \& Jomo, 1999) and subsidies granted to connected firms.

From a legal perspective, connected firms are found to have favourable regulatory treatment from the government (Agrawal \& Knoeber, 2001; Firth, Rui, \& Wu, 2011; Faccio, 2006). Referring to the political power hypothesis argued under the stakeholder salience theory, connected firms in China have been observed to enjoy high tax incentives due to the positive ties that help to decrease tax burden (Huang \& Zhao 2016). Researchers have further suggested that creating a relationship with politicians with power leads to certain advantages, particularly on tax preferences. A study conducted after the financial crisis in 1997/98 has suggested that a high percentage of distressed firms in Malaysia were bailed out, especially those that were connected to the three most powerful politicians during that period (Gomez \& Jomo, 1999). However, the effects from the systematic exchange of favours between firms and the politicians, as directors, has promoted the opportunistic behaviour of political directors to deviate some of the firms' resources for their political advantage. These adverse effects of political influence can be seen as the grabbing hand effect, which may be perceived as risky by stakeholders.

The paradoxical impact of political influence in business decisions have increased stakeholders' demand for transparency through disclosure. This demand has pushed managers to increase their voluntary disclosure to help stakeholders' decisions. The increased disclosure of information in the connected firms may not only bridge 
the information gap between firms and stakeholders but may also signal the investment opportunities and benefits that arise due to the ties. The salient effects of political influence that are prevalent in corporate strategic planning have led us to study the role of such influence on disclosure. To develop the hypothesis, we use certain disclosure theories to explain the behaviour of disclosure practices among firms. The reasons for managers to voluntarily disclose additional information about the future are normally bound by signalling, proprietorship cost and litigation risk theories, as shown in Figure 1.

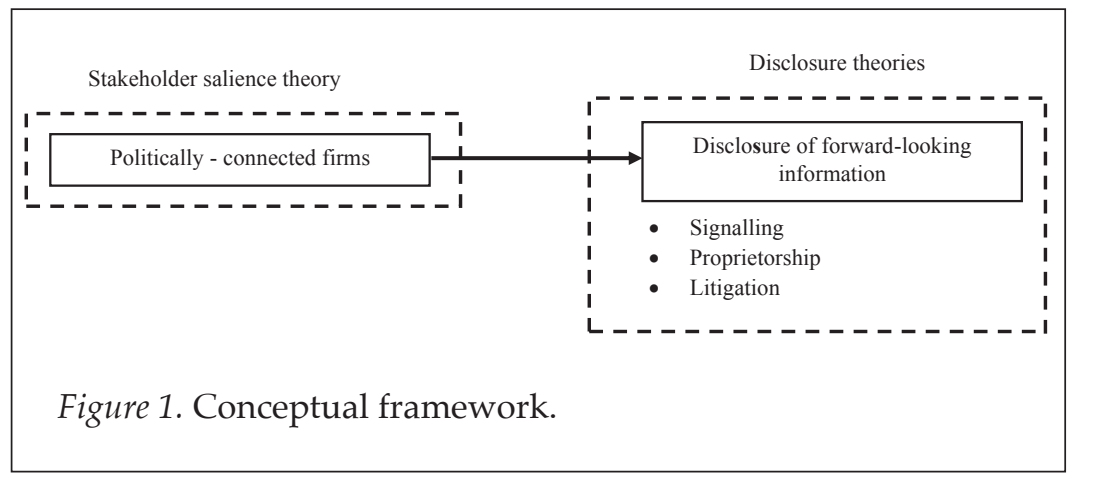

In most of the prior studies on disclosure, the limited disclosure among connected firms indicates high agency cost, which explains the ineffective role of the monitoring mechanisms (Boubakri, Ghoul, \& Saffar, 2013; Guedhami \& Pittman, 2006; Sepasi, Kazempour, \& Mansourlakoraj, 2016; Shiri, Salehi, \& Radbon, 2016). The poor quality of disclosure exhibited by connected firms results in high earnings management (Yasser, Mamun, \& Hook, 2017), and expropriation activities, i.e., misuse of power by politicians through improper channels of favours to their cronies in exchange for political support, bribes and nepotism (Bushman, Piotroski, \& Smith, 2004; Chaney, Faccio, \& Parsley, 2011; Mohammed, Ahmed, \& Ji, 2017; Riahi-Belkaoui, 2004). Hence, these practices may increase the risk of litigation. The benefits from such ties may provide fewer incentives for the connected firms to improve their disclosure quality (Chaney et al., 2011; Hung et al., 2018; Leuz \& Oberholzer-Gee, 2006).

However, some cases in developing countries have suggested that connected firms disclose more forward-looking information than 
non-connected firms. This claim is supported by Tsai et al. (2019), who document that connected firms disclose more forward-looking information. Access to confidential government information and its tangible and intangible resources (Kumlin \& Rothstein, 2005) provides politicians the advantage of supplying such information to the firms. Politicians on the boards of firms can reduce uncertainties about government policies and plans. Considering the nature of politicians who are very much involved in policy-making and foreseeing the future, the information provided by political directors may reduce the impact of uncertainties in the future, thus mitigating the effects of information asymmetry. Moreover, the alignment of strategic plans of connected firms and government policies may increase the demand of such connections; moreover, the connection is treated as a way to reduce the agency cost (Rusli et al., 2019). Prior literature has supported the notion that political directors are prone to providing unique information about public policy, which is often very expensive or difficult for a firm to obtain (Hillman et al., 2000). Therefore, we believe that the level of forward-looking information disclosure by connected firms may vary more than that of non-connected firms due to the effects of the salient role of politicians as directors in the firms.

Following the proprietorship cost theory, the disclosure of forwardlooking information may increase the competitive disadvantage of firms, thus increasing the firm's proprietorship cost. However, given the gains of the ties, the high disclosure of government contracts by connected firms may not dispossess their competitive advantage as they are protected by the government (Hung et al., 2018). In such circumstances, the connected firms not only enjoy lower proprietorship cost but also have low litigation risk due to the shield. As such, this study sheds some light on the conflicting results exhibited in prior literature. The benefits of high disclosure of forward-looking information also provide slim chances for tunnelling activities among politically-connected firms (Liu \& Sun, 2010). It is also useful as a protective mechanism for minority shareholders, particularly in countries with weak protection of minority interests (Lakhal, 2015).

Hence, we predict that:

$\mathrm{H}_{1}$ : Political connections is positively related to forward-looking information. 
To examine the strength of political connections on a firm's disclosure level further, we use the stakeholder salience theory as a foundation to predict the relationship. The theory is defined as follows:

\section{Stakeholder Salience Theory}

The concept of salience is used to analyse the effects of managerial evaluation of stakeholders' priority levels when they deal with conflicting stakeholders' needs (Huang et al., 2016). Particularly, the comprehensive judgement of managers' evaluation on the stakeholders' importance level has created a ranking of stakeholders from the managers' perspective (Mitchell et al., 1997). As proposed by Mitchell, Agle, \& Wood, (1997), the combination of stakeholders' legitimacy, urgency and power, determines salience. Mitchell et al. (1997) further define power as the ability and method of a stakeholder to affect the company's decision. Moreover, legitimacy is a stakeholder's obligation given by law, regulations and social duty, while urgency is the stakeholder's requirement or demand that can be solved by managers.

We consistently agree with Tsai et al. (2019) that the resources brought in by political connections may vary with the strength of those connections. Following Huang et al. (2016), the political power and the foundation of alliances can influence the stakeholders' relative importance. From the political perspective, the hierarchy of politicians in the political system indicates a range of political power in accessing government resources and in channelling the allocation of resources to the firms. In other words, higher political positions may provide more information as they have access to the government's classified information about the future, which may be beneficial to the firm's strategic plans. Given that the government has control of almost all crucial resources, we believe that the hierarchical position of politicians in the political system may impact the disclosure information of forward-looking information. Besides the strength, we also examine the composition of political connections that influence the firm's disclosure choices.

Hence, we predict that:

$\mathrm{H}_{2}$ : The strength of political connection is positively associated with the disclosure of forward-looking information. 


\section{Methodology}

\section{Data Sample and Variable Description}

The sample includes all publicly listed firms on Bursa Malaysia between 2014 and 2017, except those in the financial industry. The exclusion of this industry from the sample is due to different reporting regulations and the industry's unique characteristics (Embong, Mohd-Saleh, \& Sabri Hassan, 2012; Jaffar \& Abdul-Shukor, 2016; Rajan \& Zingales, 1998). We choose the firms listed on the Main Board because they are large and endowed with resources, which will give more variation in the disclosure level (Embong et al., 2012; Lang \& Lundholm, 1996). In relation to data collection, we use firms' annual reports to gather forward-looking information. Hence, firms with no annual reports are dropped from the sample. We use these reports as a source of information because it is a primary channel to distribute information, particularly forward-looking information. Directors may use this platform for future planning or signalling any potential gains or threats that are useful for investors when making investment decisions. Besides, the publication of these annual reports is claimed to be not subject to potential re-interpretation and distortion by the media (Kent \& Ung, 2003). We extract financial data from the Thomson Reuters Datastream. Only firms with complete financial data of four consecutive years are considered to be part of the sample. Therefore, the final sample of our study is 90 firms or equivalent to 360 firm-year observations. In Table 1, we provide a brief summary of sampling criteria that led to the final sample.

Table 1

Sampling Criteria Description

\begin{tabular}{lc}
\hline Criteria of sample & No. of obs. \\
\hline No. of non-financial observations (2014 and 2017) & 1.072 \\
No. of observations without annual report & $(222)$ \\
No. of observations with missing values & $(336)$ \\
No. of observations with no consecutive data & $(154)$ \\
No. of final observations in the sample (firm-year) & 360 \\
\hline
\end{tabular}


As for independent variables, we determine political connections using a dummy variable of 1 if the firms are politically-connected through either directorship or ownership, and 0 , if not connected. We define political connections in two different channels following Faccio (2006) and Boubakri et al. (2012), with a few modifications according to Malaysian practices. As suggested by Boubakri et al. (2012), Faccio (2006) classifies politically connected firms into two main categories of directorship or ownership. On the one hand, connection through directorship is identified if anyone among a firm's top officers, namely, the Chief Executive Officers (CEO), chairperson of the board, president, vice-president or secretary, is a member of the parliament, a minister or a head of state. However, we also include closely related firms, defined as firms that have directors who have been previously appointed in one of the government linked companies (GLCs). On the other hand, firms owned by the government (with at least $10 \%$ of voting rights), or so-called GLCs, are identified as politicallyconnected. This classification identifies that 67 firms are politicallyconnected.

\section{Table 2}

Weights of Different Bureaucracy Levels

\begin{tabular}{lc}
\hline & Tsai et al. (2019) \\
\hline Level of bureaucracy & Weight \\
Central government & 5 \\
Provincial level & 4 \\
Prefectural level & 3 \\
County level & 2 \\
Township level and below & 1 \\
& Author's mapping \\
Minister & 4 \\
Member of Parliament & 3 \\
Chief Minister \& State & 2 \\
Assemblymen & 1 \\
Closely related & \\
\hline
\end{tabular}


We use two proxies for strength of political connections, following Tsai et al. (2018), a weighted index, and Francis et al. (2009), using the composition of a political director on the board. The weighted index proposed by Tsai et al. (2019) is based on the network centrality of the politician. The higher the position of the politician is in the political system (towards the central government), the higher the weighted index will be. We map the weighted index according to the Malaysian political environment as follows:

Next, we develop a strength index of different bureaucratic levels (BUREAULVL) by summing up the weights for each observation. As for the dependent variable, we adopt a text-unit analysis from Abed et al. (2016) using a list of keywords and topics/themes under the forward-looking perspective to measure the level of forwardlooking information disclosure. ${ }^{1}$ Then, focusing on both financial and non-financial forward-looking information, we further expand the non-financial information into three different themes, i.e., environment, strategy and structure information. We measure the level of disclosure of forward-looking information by capturing the intersections of the keywords of forward-looking information and the keywords of themes as provided in Appendix A. The computerised method using the NVIVO software for identifying and measuring the level of forward-looking information disclosure of the firms listed in Malaysia helps increase the reliability and consistency of the findings (Morris, 1994).

In this study, we also control for the factors that affect the level of forward-looking information disclosure to obtain appropriate inferences. The factors considered as control variables are crossfirm differences in leverage (Al-Najjar \& Abed, 2014; Alkhatib, 2014; O'Sullivan, Percy, \& Stewart, 2008; Wang \& Hussainey, 2013); firm size (Hussainey \& Al-Najjar, 2011; Wang \& Hussainey, 2013; Althanasakou \& Hussainey, 2014); board size (Al-Najjar \& Abed, 2014; Elgammal, Hussainey, \& Ahmed, 2018); firm age (Aljifri, , Hussainey, \& Oyelere, 2013; Qu, Ee, Liu, Wise, \& Carey, 2015; Uyar \& Kilic, 2012); growth (Hussainey \& Al-Najjar, 2011; Athanasakou \& Hussainey, 2014); profitability (Hussainey \& Al-Najjar, 2011; Wang \& Hussainey, 2013; Athanasakou \& Hussainey, 2014); choice of auditor (Alkhatib 2014b; Lan, Wang, \& Zhang, 2013); and the number of 
independent directors on the board (Gisbert \& Navallas, 2013; Liu, 2015). We also control for the effects of years and industry types that can influence the firm's disclosure level. The Table on variable measurements is presented in Appendix 2. The models are as follows:

\section{Regression Models}

\section{Model 1:}

$$
\begin{aligned}
\text { FWDLOOK }_{i t} & =\beta_{0}+\beta_{1}\left(\text { CONNECT }_{i t}+\beta_{2}(\text { INDPDIR })_{i t}+\beta_{3}(\text { BIG4 })_{i t}+\beta_{4}(\text { SIZE })_{i t}\right. \\
& +\beta_{5}(\text { LEV })_{i t}+\beta_{6}(\text { BTM })_{i t}+\beta_{7}(\text { AGE })_{i t}+\beta_{8}(\text { ROA })_{i t}+\beta_{9}(\text { BODSIZE })_{i t} \\
& +\sum_{i=1}^{n} \beta(\text { INDUSTRY })_{i t}+\sum_{i=1}^{n} \beta(\text { YEAR })_{i t}+\varepsilon_{i t}
\end{aligned}
$$

where subscript $i$ refers to firm, $t$ refers to time, and:

FWDLOOK is forward-looking information measured by a natural log of firm's total number of text units of forward-looking information (both financial (FINFL) and non-financial forward-looking (NONFINFL) information types) at the end of the year.

CONNECT is political connection - a firm is considered politicallyconnected using the weighted index (BUREAULVL) by Tsai et al. (2018), and the composition of political directors on the board (PCONDIR) following Francis et al. (2009).

INDPDIR is board independence, measured as a natural log of the proportion of independent directors to total number of board members BIG4 is quality audit, defined as a dummy variable that is equal to 1 if the firm is audited by one of the big 4 audit firms (PWC, EY, DKC and KPMG), and 0, otherwise.

SIZE is firm size, measured by a natural log of firm's total assets.

$L E V$ is leverage, i.e., total debt to total assets ratio.

BTM is measured for growth and computed as a natural log of book value to the market value of equity.

$A G E$ is firm age, measured by a natural log of firm age estimated from the establishment year. 
$R O A$ is firm performance, measured by a firm's return on assets (net profit over total assets).

BODSIZE is board size, defined as a natural log of total number of directors on the board.

INDUSTRY refers to dummy variables controlling for industry effects (across eight industries).

YEAR are year dummy variables $\varepsilon$ is an error term

Model 1 exhibits an estimation of the main predictor, political connection (CONNECT), to estimate the level of forward-looking information disclosure (FWDLOOK). To test for the political influence on the level of the disclosure, we regress CONNECT on FWDLOOK and its types, i.e., financial forward-looking information (FINFL) and non-financial forward-looking information (NONFINFL) as shown in Models 1, 4 and 5 (Table 6) ${ }^{2}$. To estimate the strength of the connection on FWDLOOK further, the index of strength (BUREAULVL) by Tsai et al. (2019) and the composition of politically connected firms' director (PCONDIR) following Francis et al. (2009), are used to replace $(C O N N E C T)_{i t}$ as shown in Model 2. The strength using both proxies is also estimated to predict the level of types of forward-looking information (FINFL and NONFINFL) as shown in Models 6 and 7.

Given that the political connection can be formed through directorship (DIRSHIP) and ownership (OWNSHIP), CONNECT is divided into DIRSHIP and OWNSHIP and regressed on the FWDLOOK and its types (FINFL and NONFINFL) as shown in Models 3, 8 and 9 in Table 6 . We believe the types of the connection may give a variation on the level of disclosure as argued by Huang et al. (2016) and Tsai et al. (2019).

\section{Discussion of Findings}

As for the dependent variable, the natural log of the number of textunits is used to measure the level of disclosure of forward-looking information (FWDLOOK). 
IJMS 27(2), 47-76 (2020)

Table 3

Descriptive Statistics for Variables

\begin{tabular}{lccccc}
\hline & Mean & Median & $\begin{array}{c}\text { Standard } \\
\text { Deviation }\end{array}$ & Min. & Max. \\
\hline FWDLOOK & 3.40 & 3.38 & 0.73 & 2.08 & 4.65 \\
FINFL & 2.08 & 2.08 & 0.70 & 0.69 & 3.30 \\
NONFINFL & 3.04 & 3.05 & 0.89 & 0.00 & 5.05 \\
CONNECT & 0.73 & 1.00 & 0.45 & 0.00 & 1.00 \\
BUREAULVL & 0.15 & 0.10 & 0.17 & 0.00 & 1.00 \\
PCONDIR & 0.23 & 0.20 & 0.22 & 0.00 & 0.89 \\
BODSIZE & 2.16 & 2.20 & 0.24 & 1.61 & 2.71 \\
SIZE & 2.70 & 2.69 & 0.10 & 2.53 & 2.87 \\
LEV & 0.35 & 0.31 & 0.18 & 0.13 & 0.77 \\
BTM & 4.20 & 4.19 & 0.64 & 3.10 & 5.45 \\
AGE & 2.55 & 2.89 & 0.84 & 0.69 & 3.43 \\
BIG4 & 0.92 & 1.00 & 0.27 & 0.00 & 1.00 \\
ROA & 1.71 & 1.77 & 0.87 & -4.61 & 3.54 \\
INDPDIR & 0.45 & 0.43 & 0.12 & 0.25 & 0.78 \\
\hline
\end{tabular}

Note: FWDLOOK is forward-looking information; FINFL is financial forward-looking information; NONFINFL is non-financial forward-looking information; CONNECT is political connection; BUREAULVL is defined as index of political strength following Tsai et al. (2019); PCONDIR is defined as the composition of board of directors following Francis et al. (2009); INDPDIR is board independence; BIG4 is quality audit; SIZE is firm size; LEV is leverage; BTM is firm growth; AGE is firm age; ROA is firm performance; and BODSIZE is board size. All variables are as defined in Equation (1).

Table 3 shows the mean of log-transformed text units of 3.40 or equivalent to 38.97 text-units with a maximum value of 4.65 or 105 text-units and a minimum value of 2.08 or eight text-units. Of the mean values, a value of 3.04 or equivalent to 29.99 text-units is reported to be non-financial forward-looking information (NONFINFL), whereas financial forward-looking information (FINFL) is reported at 2.08 or 10.54 text-units. The initial statistics show that firms tend to disclose 
more NONFINFL than FINFL. The findings are initially supported by Liu (2015) and Orens, Aerts and Lybaert (2013) as they find that the soft qualitative types of disclosure or NONFINFL information is highly reported by firms in China and European countries. Hence, this evidence supports the argument suggested by Uyar and Kilic (2012) and Kent and Ung (2003), that firms disclose more qualitative future information. Inversely, the low level of FINFL information disclosure suggests high potential of litigation risk, thus curbing managers' behaviour from disclosing additional information (Brockman \& Cicon, 2013).

Table 4

Difference between Types of Connections

\begin{tabular}{lllll}
\hline & \multicolumn{4}{c}{ Mean } \\
\cline { 2 - 4 }$N$ & DIRSHIP & OWNSHIP & BOTH & \multirow{2}{*}{ F-stats } \\
\cline { 2 - 4 } & 118 & 10 & 140 & \\
\cline { 2 - 4 } FWDLOOK & 3.20 & 3.69 & 3.79 & $27.65^{*}$ \\
FINFL & 1.89 & 2.49 & 2.39 & $17.55^{*}$ \\
NONFINFL & 2.84 & 3.31 & 3.49 & $25.12^{*}$ \\
BODSIZE & 2.15 & 2.00 & 2.24 & $16.52^{*}$ \\
SIZE & 2.69 & 2.63 & 2.75 & $29.61^{*}$ \\
LEV & 0.35 & 0.31 & 0.38 & 1.13 \\
BTM & 4.34 & 4.02 & 4.21 & 1.63 \\
AGE & 2.49 & 2.14 & 2.48 & 2.13 \\
BIG4 & 0.90 & 0.90 & 0.98 & 3.74 \\
ROA & 1.71 & 1.85 & 1.61 & 3.33 \\
INDPDIR & 0.45 & 0.47 & 0.49 & $7.64^{*}$ \\
\hline
\end{tabular}

Note: FWDLOOK is forward-looking information; FINFL is financial forward-looking information; NONFINFL is non-financial forwardlooking information; CONNECT is political connection; INDPDIR is board independence; BIG4 is quality audit; SIZE is firm size; LEV is leverage; BTM is firm growth; AGE is firm age; ROA is firm performance; and BODSIZE is board size. All variables are as defined in Equation (1). DIRSHIP is a firm that is politically-connected through directorship; OWNSHIP is a firm that is politically-connected through equity holding; $B O T H$ is a firm that is politically-connected through both DIRSHIP and OWNSHIP. ${ }^{*} p<0.01$. 
Table 4 shows the ANOVA statistics to examine the differences in mean values among the types of connection used in the regressions. From the Table, the mean values of FWDLOOK level between the types of connection, namely, DIRSHIP, OWNSHIP and BOTH, are statistically different at the $1 \%$ level of significance. The disclosure level of FWDLOOK and its types (FINFL and NONFINFL) also show significant difference at the $1 \%$ level among the types of connection. This evidence shows that a separate analysis of disclosure behaviour based on the types of connection is warranted. Table 5 exhibits the correlation matrix with an initial relationship among variables, and the coefficient value is useful for signalling multicollinearity problems. The results show that FWDLOOK and CONNECT are positively correlated $(p=0.27)$, suggesting that PCONS promotes the FWDLOOK. However, the strength of PCONS is only positively significant (at conventional level) for Francis et al.'s (2009) approach, which uses the composition of the political directors on the board.

Referring to the types of disclosure, the connected firms (CONNECT) promote more NONFINFL $(p=0.28)$ than FINFL $(p=-0.30)$ types. However, further analysis must be conducted to validate the initial findings. The highest coefficient from the correlation is at 0.51 (exclusion for types of connection and types of forward-looking information) and is lower than the threshold at 0.8 , suggesting that multicollinearity is not a serious concern in our regression (Hair, Black, Babin, Anderson, 2011). 
IJMS 27(2), 47-76(2020)

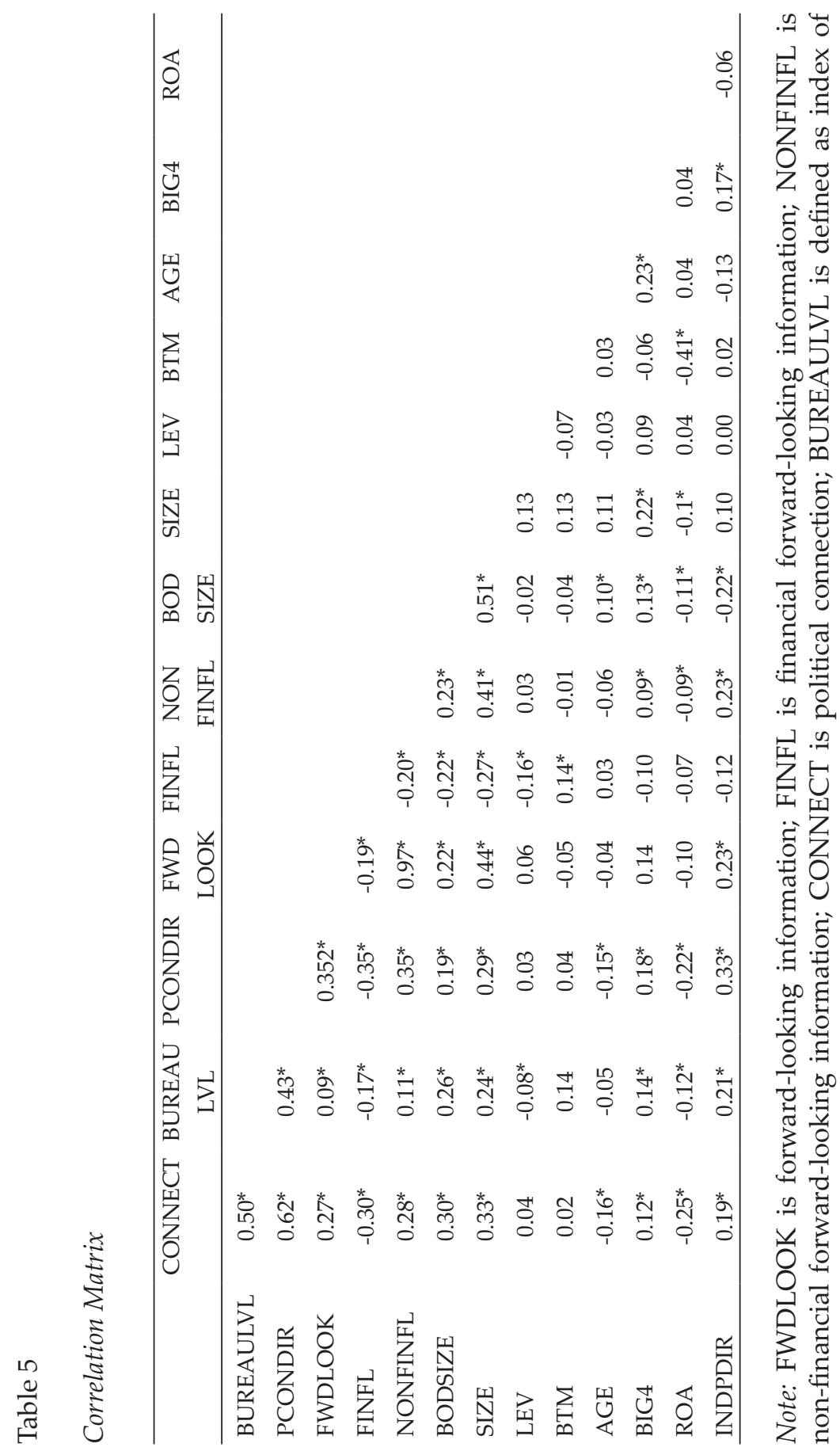


political strength following Tsai et al. (2019); PCONDIR is defined as the composition of board of directors following Francis et al. (2009); DIRSHIP is a firm that is politically-connected through directorship; OWNSHIP is a firm that is politically-connected through equity holding; BODSIZE is board size; SIZE is firm size; LEV is leverage; BTM is firm growth; AGE is firm age; BIG4 is quality audit; ROA is firm performance; and INDPDIR is board independence. All variables are as defined in Equation (1). ${ }^{*} p<0.01$.

\section{Regressions Results}

To test the research model, this study uses multiple regression analysis for panel data between 2014 to 2017 across industries. Several assumptions are tested to ensure that the data fulfils the normality and homoscedasticity assumptions. Table 6 reports panel-random effects of the OLS estimation using the robust White covariance method to remedy the heterocedasticity problems in the regression of FWDLOOK, FINFL and NONFINFL by political connection, strength and types of connection.

Referring to Model 1 in Table 6, we find that CONNECT is positively and significantly related to $F W D L O O K$ at the $1 \%$ level. This result suggests that the disclosure level of forward-looking information is higher for connected firms. Specifically, the estimated coefficient of CONNECT posits that PCONS disclose FWDLOOK 21 points higher than non-PCONS. This finding is consistent with the results found by Liu (2015), Huang and Zhao (2016) and Du et al. (2009). However, the positive effects of CONNECT to promote FWDLOOK are only significant for NONFINFL types (see Model 5). The high disclosure of NONFINFL by the connected firms is consistently supported by Kent and Ung (2003), showing that Australian PCONS disclose more qualitative forward-looking information as it helps investors in investment decisions. Also, in China, the government encourages listed firms on the Shanghai Stock Exchange to disclose mainly NONFINFL about their future prospects and development, as one of the efforts to obtain financing facilities (Cheng, Youchao, \& Jianmei, 2012). Moreover, litigation risk provides fewer incentives to managers to disclose FINFL, particularly when the target is not achievable and such disclosure can mislead the investors' decisions and bring unfavourable outcomes to the investors (Al-Najjar \& Abed, 2014; Aljifri \& Hussainey, 2007; Bravo, 2016; Tan, Xu, Liu, \& 
Zeng, 2015; Wang \& Hussainey, 2013). In sum, the findings partially support Hypothesis $2\left(\mathrm{H}_{2}\right)$, which posits that PCONS disclose more NONFINFL than non-PCONS.

Furthermore, the result suggests the efficient role of political directors in providing additional disclosure of forward-looking information in their capacity as politicians. The high disclosure of NONFINFL also signifies that the connected firms may have more prospects than non-connected firms in investment opportunities due to their link to the government. Considering the nature of politicians who are involved in policy-making and foreseeing the future, connections with the government help firms to improve their forward-looking disclosure level. This support can reduce the agency cost as political directors have been reported as having conflicting objectives between commercial enterprises and national interests (Wang, Wong, \& Xia., 2008). Hence, Hypothesis $1\left(\mathrm{H}_{1}\right)$ is supported.

Table 6

Regression Estimations for all Models

Model

1

FWDLOOK

2 3

\begin{tabular}{lcr} 
& FWDLOOK & FWDLOOK \\
\hline CONNECT & $0.21^{* * *}$ & \\
& $(4.73)$ & \\
BUREAULVL & & -0.16 \\
PCONDIR & & $(-0.90)$ \\
& & $0.47^{* * *}$
\end{tabular}

(6.30)

DIRSHIP

$-0.04$

$(-0.59)$

OWNSHIP

$0.42^{* * *}$

(7.78)

BODSIZE

$-0.29^{* *}$

$-0.26$

$-0.26^{* *}$

$(-2.21)$

(-1.01)

SIZE

$2.83^{* * *}$

$3.10^{* * *}$

$2.66^{* * *}$

(6.54)

(6.11)

(6.98)

(continued) 
IJMS 27(2), 47-76 (2020)

\begin{tabular}{|c|c|c|c|}
\hline & \multirow[b]{2}{*}{1} & \multicolumn{2}{|c|}{ Model } \\
\hline & & 2 & 3 \\
\hline & FWDLOOK & FWDLOOK & FWDLOOK \\
\hline \multirow[t]{2}{*}{ BTM } & $-0.07^{* * *}$ & $-0.04^{* *}$ & $-0.05^{* *}$ \\
\hline & $(-5.65)$ & $(-2.39)$ & $(-2.33)$ \\
\hline \multirow[t]{2}{*}{ AGE } & -0.05 & -0.04 & -0.05 \\
\hline & $(-0.95)$ & $(-0.68)$ & $(-1.09)$ \\
\hline \multirow[t]{2}{*}{ BIG4 } & $0.28^{* * *}$ & $0.28^{* * *}$ & $0.24^{* * *}$ \\
\hline & $(2.81)$ & (3.18) & (3.11) \\
\hline \multirow[t]{2}{*}{ ROA } & $-0.07^{* * *}$ & -0.00 & $-0.07^{* * *}$ \\
\hline & $(-4.33)$ & $(-0.61)$ & $(-5.33)$ \\
\hline \multirow[t]{2}{*}{ INDPDIR } & -0.03 & -0.01 & -0.03 \\
\hline & $(-0.30)$ & $(-0.02)$ & $(-0.38)$ \\
\hline \multirow[t]{2}{*}{ Constant } & $-3.48^{* *}$ & $-4.16^{* * *}$ & $-2.96^{* *}$ \\
\hline & $(-2.39)$ & $(-3.16)$ & $(-2.30)$ \\
\hline Industry effect & Yes & Yes & Yes \\
\hline Year effect & Yes & Yes & Yes \\
\hline Adj. $R^{2}$ & 0.20 & 0.18 & 0.22 \\
\hline F-stats & 4.90 & 5.18 & 5.18 \\
\hline
\end{tabular}

Table 6

Regression Estimations for all Models (cont')

\begin{tabular}{lcccccc}
\hline & & \multicolumn{4}{c}{ Model } & \\
& 4 & 5 & 6 & 7 & 8 & 9 \\
& FINFL & NONFINFL & FINFL & NONFINFL & FINFL & NONFINFL \\
\hline CONNECT & 0.07 & $0.29^{* * *}$ & & & & \\
& $(0.45)$ & $(4.61)$ & & & \\
BUREAULVL & & & -0.18 & -0.02 & \\
PCONDIR & & & $(-0.59)$ & $(-0.12)$ & \\
& & & 0.07 & $0.36^{* *}$ & \\
\hline
\end{tabular}

(continued) 
IJMS 27(2), 47-76(2020)

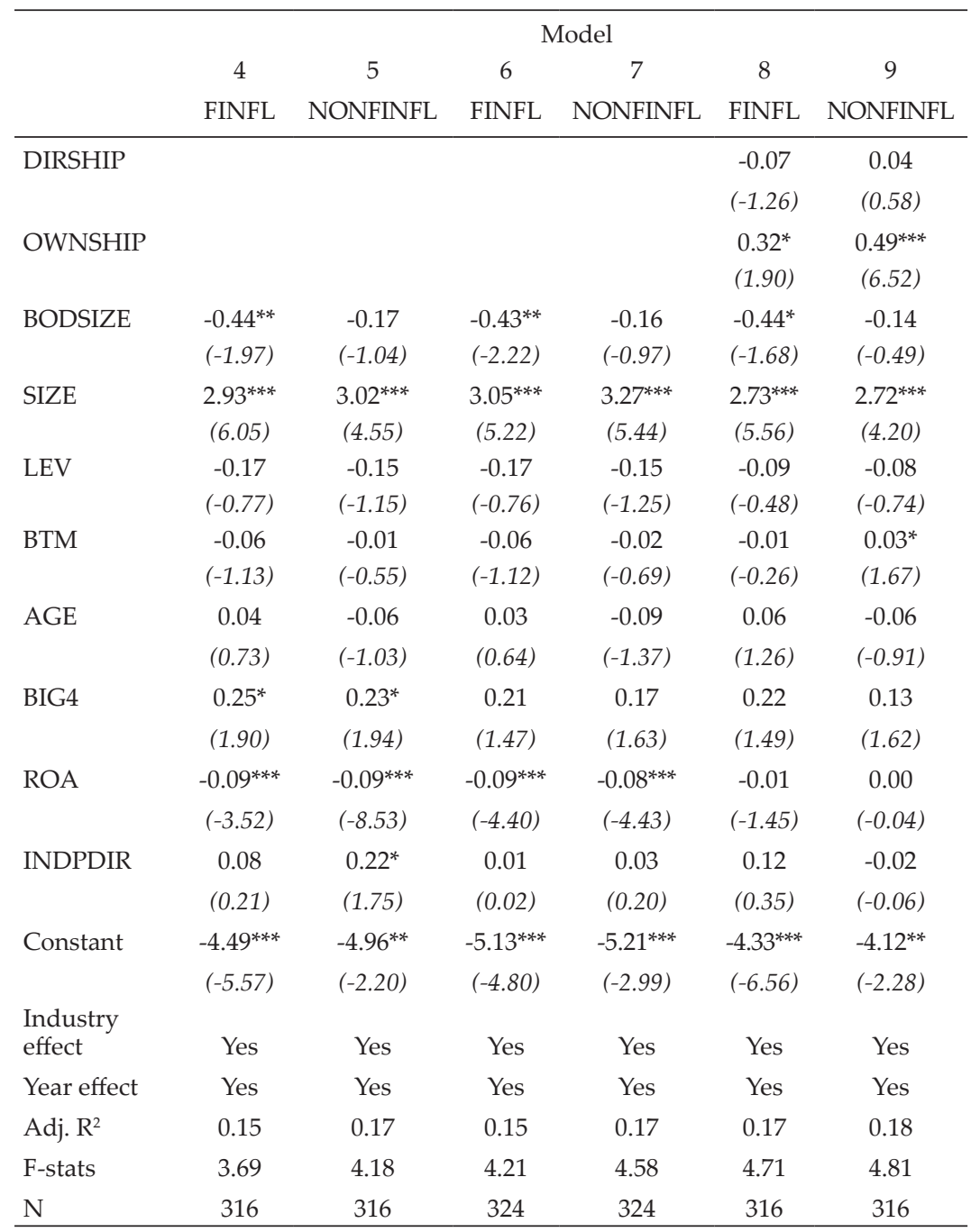

Note: FWDLOOK is forward-looking information; FINFL is financial forward-looking information; NONFINFL is non-financial forward-looking information; CONNECT is political connection; BUREAULVL is defined as index of political strength following Tsai et al. (2019); PCONDIR is defined as the composition of board of directors following Francis et al. (2009); DIRSHIP is a firm that is politically-connected through directorship; OWNSHIP is a firm that is politically-connected through equity holding; BODSIZE is board size; SIZE is firm size; LEV is leverage; BTM is firm growth; AGE is firm age; BIG4 is quality audit; ROA is firm performance; and INDPDIR is board independence. All variables are as defined in Equation (1). Figures in parentheses are t-statistics. ${ }^{* * *} p<0.01,{ }^{* *} p<0.05$ or ${ }^{*} p<0.10$.. 
Looking at the strength of the political connection indicators shown in Model 2, the weighted index suggested by Tsai et al. (2019) indicates an insignificant effect of BUREAULVL $(\mathrm{p}=-0.16, \mathrm{t}=-0.90) \quad(\mathrm{p}=-0.16$, $\mathrm{t}=-0.90$ ) on forward-looking information disclosure. However, the high composition of PCONDIR in the board structure has a positive value ( $\mathrm{p}=0.47, \mathrm{t}=6.30$ ) and is significantly related to $F W D L O O K$ at the $1 \%$ level. This finding suggests that the high composition of PCONS directors on the board explains their great capacity to effectively perform their duty as information providers. Instead of the power of network centrality, the high number of politicians on the board is more meaningful to help firms to improve their transparency level. The results also show that the selection of a proxy to measure political strength is important to infer the findings. Therefore, the stakeholder salience theory, which predicts the power, urgency and legitimacy of high political leaders to supply information about the future, is supported using the Francis et al. (2009) approach.

In additional analyses, we determine the types of connection on forward-looking disclosure. From Model 3, the positive coefficient value of OWNSHIP, $0.42(\mathrm{t}=7.78)$ at the $1 \%$ significance level, fulfils our expectation that firms connected through OWNSHIP may have greater FWDLOOK disclosure than DIRSHIP due to the collective capacity of politicians as directors of firms. This result is consistently aligned with our earlier findings using the Francis et al. (2009) approach. As we further analyse the sample according to the types of disclosure (Models 8 and 9), firms connected through OWNSHIP show a consistent association to NONFINFL at a conventional significance level ( $p=0.49, t=6.52$, Model 9). The difference of a 49.3-point basis, which is higher for firms connected through OWNSHIP, suggests that high composition of stakes in the firm allows the government to provide additional forward-looking information to help investors accurately predict the future.

Following the literature on disclosure, the presence of politicians in most GLCs in Malaysia has improved the disclosure quality used as a mechanism to bridge the information gap between firms and investors (Wang \& Hussainey, 2013). The argument supporting high disclosure among GLCs is also documented by Eng and Mak (2003), as it reflects the promotion of a comprehensive development for social interest. The advantages to enhance the disclosure of forward- 
looking information are more critical when a firm has a large number of institutional shareholders. The dissemination of information through narratives in the disclosure is more cost-effective than the direct meetings with them (Wang \& Hussainey, 2013).

Control variables, namely, big firm SIZE, high growth firms (BTM) and audited by BIG4, are found to be capable of disclosing quality information voluntarily as they have sufficient resources to bridge the information asymmetry gap, which can reduce the agency cost (Abed \& Al-Najjar, 2016; Akhtaruddin, Hossain, Hossain, \& Yao, 2009; Dhaliwal, Li, Tsang, \& Yang, 2011; Lang \& Lundholm, 1996; O'Sullivan et al., 2008). As for the ROA, high profitability firms are less likely to disclose additional forward-looking information; this observation is consistently supported by previous scholars (Hussainey \& AlNajjar, 2011). Researchers have further suggested that the benefits of disclosing forward-looking information by low-performing firms will create additional benefits in the future (Alkhatib, 2014; Hussainey \& Al-Najjar, 2011).

From the overall results, the adjusted $\mathrm{R}^{2}$ of the regression analyses throughout the models range between 14 percent and 22 percent, which is comparable to Hung et al. (2018) in the international setting. Therefore, the influence of political connections in determining firms' disclosure policy may be considerably impacted by the types of connections.

\section{Conclusion}

This study examines the effect of political connections on firms' forward-looking information disclosure within the context of developing countries. Using 360 firm-year observations of nonfinancial firms listed on Bursa Malaysia between 2014 and 2017, the political forces may considerably impact the disclosure level of forward-looking information. Using the stakeholder salience theory to explain the disclosure behaviour of connected firms, the power of political directors and high government stakes through ownership in firms as information providers that help managers to formulate strategic plans that are aligned with the policy, has improved the level of NONFINFL types. This suggests the capacity of political directors 
to perform their duty to steer the firms towards the future through the provision of forward-looking information.

The implication of this research may pave the way for firms' disclosure choices of forward-looking information under the perspective of political influence. As suggested under the abovementioned theory, the power, urgency and legitimacy brought by a political director to improve a firm's forward-looking disclosure may be beneficial for regulators in establishing guidelines for the best practices of preparing such disclosure. This perspective can complement our understanding on the role of directors in monitoring governance, which is predominantly explained by the agency perspective. Practically, requirements and conditions for effective politicians in business are still subject to further research. At the very least, the evidence suggests that politicians' involvement can increase market participants. Nevertheless, this study comes with several limitations. Firstly, the weight of the power of network centrality may not be suitable for the political environment in Malaysia. Our economic system is practised based on close- and near-relationship businesses. Therefore, rather than the central government, we believe the power of politicians to control resources is stronger in firms connected at the state-level. This factor can provide opportunities for future research to weigh the political strength based on close- and near-relationship businesses, such as that in the Malaysian setting. Secondly, our sample is limited to only non-financial listed firms. Thus, generalisability may be an issue. Moreover, our data only covers a four-year period. The strength of political connections may not have yet developed during this period.

\section{Acknowledgement}

The authors wish to thank the generous funding from the Tun Ismail Mohd. Ali Foundation under grant EP-2018-008.

\section{Endnotes}

1 The list of keywords and topics/themes are presented in Appendix 1. 
2 For simplicity, we only show the equation for Model 1 . This equation can be expanded into Models 2 to 9 by replacing the variables as explained.

\section{References}

Abdul Wahab, E. A., \& Abdul Rahman, R. (2009). Institutional investors and director remuneration: Do political connections matter? Advances in Financial Economics, 13, 139-169.

Abed, S., \& Al-Najjar, B. (2016). Determinants of the extent of forward looking information: Evidence from UK before financial crisis. Corporate Ownership and Control, 13(3), 17-32.

Agrawal, A., \& Knoeber, C. R. (2001). Do some outside directors play a political role? Journal of Law \& Economics, 44(1), 179-198.

Akhtaruddin, M., Hossain, M. A., Hossain, M., \& Yao, L. (2009). Corporate governance and voluntary disclosure in corporate annual reports of malaysian listed firms. Jamar, 7(1), 1-20.

Al-Najjar, B., \& Abed, S. (2014). The association between disclosure of forward-looking information and corporate governance mechanisms: Evidence from the UK before the financial crisis period. Managerial Auditing Journal, 29(7), 578-595.

Aljifri, K., \& Hussainey, K. (2007). The determinants of forwardlooking information in annual reports of UAE companies. Managerial Auditing Journal, 22(9), 881-894.

Aljifri, K., Hussainey, K., \& Oyelere, P. (2013). The determinants of forward-looking disclosure: A corporate governance perspective. Corporate Ownership and Control, 10(2A), 8-19.

Alkhatib, K. (2014). The Determinants of Forward-looking Information Disclosure. Procedia - Social and Behavioral Sciences, 109 (January 2014), 858-864.

Athanasakou, V., \& Hussainey, K. (2014). The perceived credibility of forward-looking performance disclosures. Accounting and Business Research, 44(3), 227-259.

Ball, R., Robin, A., \& Wu, J. S. (2003). Incentives versus standards: Properties of accounting income in four East Asian countries. Journal of Accounting and Economics, 36(1-3 SPEC. ISS.), 235-270.

Bliss, M. A., \& Gul, F. A. (2012). Political connection and cost of debt: Some Malaysian evidence. Journal of Banking and Finance, 36(5), 1520-1527.

Boubakri, N., Cosset, J. C., \& Saffar, W. (2008). Political connections of newly privatized firms. Journal of Corporate Finance, 14(5), 654-673. 
Boubakri, N., Ghoul, S. El., \& Saffar, W. (2013). Cash holdings of politically connected firms. Journal of Multinational Financial Management, 23(4), 338-355.

Bravo, F. (2016). Forward-looking disclosure and corporate reputation as mechanisms to reduce stock return volatility. Revista de Contabilidad, 19(1), 122-131.

Brockman, P., \& Cicon, J. (2013). The information content of management earnings forecasts: An analysis of hard versus soft information. Journal of Financial Research, 36(2), 147-174.

Bushman, R. M., Piotroski, J. D., \& Smith, A. J. (2004). What determines corporate transparency? Journal of Accounting Research, 42, 207-252.

Chaney, P. K., Faccio, M., \& Parsley, D. (2011). The quality of accounting information in politically connected firms. Journal of Accounting and Economics, 51(1), 58-76.

Cheng, X., Youchao, T., \& Jianmei, L. (2012). The non-financial information, the external financing, and the investment efficiency: A study based on the constraint of external systems. Management World (In Chinese), 28(7), 137-150.

Dhaliwal, D. S., Li, O. Z., Tsang, A., \& Yang, Y. G. (2011). Voluntary nonfinancial disclosure and the cost of equity capital: The initiation of corporate social responsibility reporting. Accounting Review, 86(1), 59-100.

Du, X., \& Xiu, Z. (2009). Institutional Environment, Blockholder Characteristics and Ownership Concentration in China. China Journal of Accounting Research, 2(2), 27-57.

Elgammal, M. M., Hussainey, K., \& Ahmed, F. (2018). Corporate governance and voluntary risk and forward-looking disclosures. Journal of Applied Accounting Research, 19(4), 592-607.

Embong, Z., Mohd-Saleh, N., \& Sabri Hassan, M. (2012). Firm size, disclosure and cost of equity capital. Asian Review of Accounting, 20(2), 119-139.

Eng, L. L., \& Mak, Y. T. (2003). Corporate governance and voluntary disclosure. Journal of Accounting and Public Policy, 22(4), 325345.

Faccio, M. (2006). Politically Connected Firms. The American Economic Review, 96(1), 369-386.

Firth, M., Rui, O. M., \& Wu, W. (2011). The effects of political connections and state ownership on corporate litigation in China. Journal of Law and Economics, 54(3), 573-607.

Francis, B. B., Hasan, I., \& Sun, X. (2009). Political connections and the process of going public: Evidence from China. Journal of International Money and Finance, 28(4), 696-719. 
Fung, S. Y. K., Gul, F. A., \& Radhakrishnan, S. (2015). Corporate political connections and the 2008 Malaysian election. Accounting, Organizations and Society, 43, 67-86.

Gisbert, A., \& Navallas, B. (2013). The association between voluntary disclosure and corporate governance in presence of severe agency conflicts. Advances in Accounting, 29(2), 286-298.

Goldman, E., Rocholl, J., \& So, J. (2009). Do politically connected boards affect firm value. Review of Financial Studies, 22(6), 23312360.

Gomez, E. T., \& Jomo, K. S. (1999). Malaysia's Political Economy: Political, Patronage and Profits. Cambridge University: Cambridge.

Guedhami, O., \& Pittman, J. A. (2006). Ownership concentration in privatized firms: The role of disclosure standards, auditor choice, and auditing infrastructure. Journal of Accounting Research, 44(5), 889-929.

Gul, F. A. (2006). Auditors' response to political connections and cronyism in Malaysia. Journal of Accounting Research, 44(5), 931-963.

Hair, J. F., Black, W. C., Babin, B. J., Anderson, R. E., \& L., T. R. (2011). Multivariate data analysis. (6th ed.). Pearson.

Hillman, A. J., Cannella, A. A., \& Paetzold, R. L. (2000). The resource dependence role of corporate directors: Strategic adaptation of board composition in response to environmental change. Journal of Management, 37(March), 235-256.

Huang, H., \& Zhao, Z. (2016). The influence of political connection on corporate social responsibility-evidence from listed private companies in China. International Journal of Corporate Social Responsibility, 1(1), 1-19.

Huang, L., \& Xiao, S. (2012). How does government ownership affect firm performance? A simple model of privatization in transition economies. Economics Letters, 116(3), 480-482.

Hung, M., Kim, Y., \& Li, S. (2018). Political connections and voluntary disclosure: Evidence from around the world. Journal of International Business Studies, 49(3), 272-302.

Hussainey, K., \& Al-Najjar, B. (2011). Future-oriented narrative reporting: Determinants and use. Journal of Applied Accounting Research, 12(2), 123-138.

Jaffar, R., \& Abdul-Shukor, Z. (2016). The role of monitoring mechanisms towards company's performance evidence from politically connected. Journal of Accounting in Emerging Economies, 6(4), 408-428. 
Johnson, S., \& Mitton, T. (2003). Cronyism and capital controls: Evidence from Malaysia. Journal of Financial Economics, 67, 351-382.

Kent, P., \& Ung, K. (2003). Voluntary disclosure of forward-looking earnings information in Australia. Australian Journal of Management, 28(3), 273-286.

Kumlin, S., \& Rothstein, B. (2005). Making and breaking social capital: The impact of welfare-state institutions. Comparative Political Studies, 38(4), 339-365.

Lakhal, N. (2015). Corporate disclosure, ownership structure and earnings management: The case of french-listed firms. Journal of Applied Business Research, 31(4), 1493-1504.

Lan, Y., Wang, L., \& Zhang, X. (2013). Determinants and features of voluntary disclosure in the Chinese stock market. China Journal of Accounting Research, 6(4), 265-285.

Lang, M. H., \& Lundholm, R. J. (1996). Corporate disclosure policy and analyst behavior. Accounting Review, 71(4), 467-492.

Leuz, C., \& Oberholzer-Gee, F. (2006). Political relationships, global financing, and corporate transparency: Evidence from Indonesia. Journal of Financial Economics, 81(2), 411-439.

Liu, G., \& Sun, J. (2010). Ultimate ownership structure and corporate disclosure quality: Evidence from China. Managerial Finance, 36(5), 452-467.

Liu, S. (2015). Corporate governance and forward-looking disclosure: Evidence from China. Journal of International Accounting, Auditing and Taxation, 25, 16-30.

Mitchell, R. K., Agle, B. R., \& Wood, D. J. (1997). Toward a theory of stakeholder identification and salience: Defining the principle of who and what really counts. Academy of Management Review, 22(4), 853-886.

Mohammed, N., Ahmed, K., \& Ji, X. (2017). Accounting conservatism , corporate governance and political connections. Asian Review of Accounting, 25(2), 288-318.

Morris, R. (1994). Computerized content analysis in management research: A demonstration of advantages \& limitations. Journal of Management, 20(4), 903-931.

O'Sullivan, M., Percy, M., \& Stewart, J. (2008). Australian evidence on corporate governance attributes and their association with forward-looking information in the annual report. Journal of Management and Governance, 12(1), 5-35.

Orens, R., Aerts, W., \& Lybaert, N. (2013). Customer value disclosure and cost of equity capital. Review of Accounting \& Finance, 12(2), $130-147$. 
Qu, W., Ee, M. S., Liu, L., Wise, V., \& Carey, P. (2015). Corporate governance and quality of forward-looking information. Asian Review of Accounting, 23(1), 39-67.

Rajan, R. G., \& Zingales, L. (1998). Which Capitalism? Lessons from the East Asian Crisis. Journal of Applied Corporate Finance, 11(3), 40-48.

Riahi-Belkaoui, A. (2004). Politically-connected firms: Are they connected to earnings opacity? Research in Accounting Regulation, 17(C), 25-38.

Rusli, M. N., Mohd Saleh, N., \& Sabri Hassan, M., HafizuddinSyah, B.A.M. (2019). Political connection types and investors' perceived risk: Evidence from Malaysia. Asian Journal of Accounting and Governance, (12), 65-76.

Sepasi, S., Kazempour, M., \& Mansourlakoraj, R. (2016). Ownership structure and disclosure quality: Case of Iran. Procedia Economics and Finance, 36(16), 108-112.

Shiri, M. M., Salehi, M., \& Radbon, A. (2016). A study of impact of ownership structure and disclosure quality on information asymmetry in Iran. The Journal for Decision Makers, 41(1), 1-10.

Tan, Y., Xu, N., Liu, X., \& Zeng, C. (2015). “Does forward-looking non-financial information consistently affect investment efficiency?" Nankai Business Review International, 6(1),2-19.

Tsai, L. C., Zhang, R., \& Zhao, C. (2019). Political connections, network centrality and firm innovation. Finance Research Letters, 28, 180184.

Uyar, A., \& Kilic, M. (2012). Influence of corporate attributes on forward-looking information disclosure in publicly traded Turkish corporations. Procedia - Social and Behavioral Sciences, 62, 244-252.

Wang, Q., Wong, T. J., \& Xia, L. (2008). State ownership, the institutional environment, and auditor choice: Evidence from China. Journal of Accounting and Economics, 46(1), 112-134

Wang, M., \& Hussainey, K. (2013). Voluntary forward-looking statements driven by corporate governance and their value relevance. Journal of Accounting and Public Policy, 32(3), 26-49.

Yasser, Q. R., Mamun, A. Al, \& Hook, M. (2017). The impact of ownership structure on financial reporting quality in the east. International Journal of Organizational Analysis, 25(2), 178-197. 
IJMS 27(2), 47-76 (2020)

\section{APPENDIX}

\section{Appendix 1}

1. List of keywords by Abed et al. (2016)

\begin{tabular}{|c|c|}
\hline Keywords & $\begin{array}{l}\text { Accelerate; Anticipate; Await; Coming (financial) year(s); Coming } \\
\text { months; Confidence, Confident; Convince; Future; Possible; } \\
\text { Estimate; Aim; Expect; Forecast; Forthcoming; Hope; Intend, } \\
\text { Intention; Likely, Unlikely; Look ahead; Look forward; Next; } \\
\text { Near term, medium term; Optimistic; Outlook; Plan; Predict; } \\
\text { Remain; Renew; Probable; Opportunity; Commitment; Further; } \\
\text { Chance; Well placed, Well positioned; Year(s) ahead; 2014/2017, } \\
\text { 2014-2017, 2014/17; 2014, 2015. ...2017. }\end{array}$ \\
\hline
\end{tabular}

2. List of forward-looking topics by Abed et al. (2016)

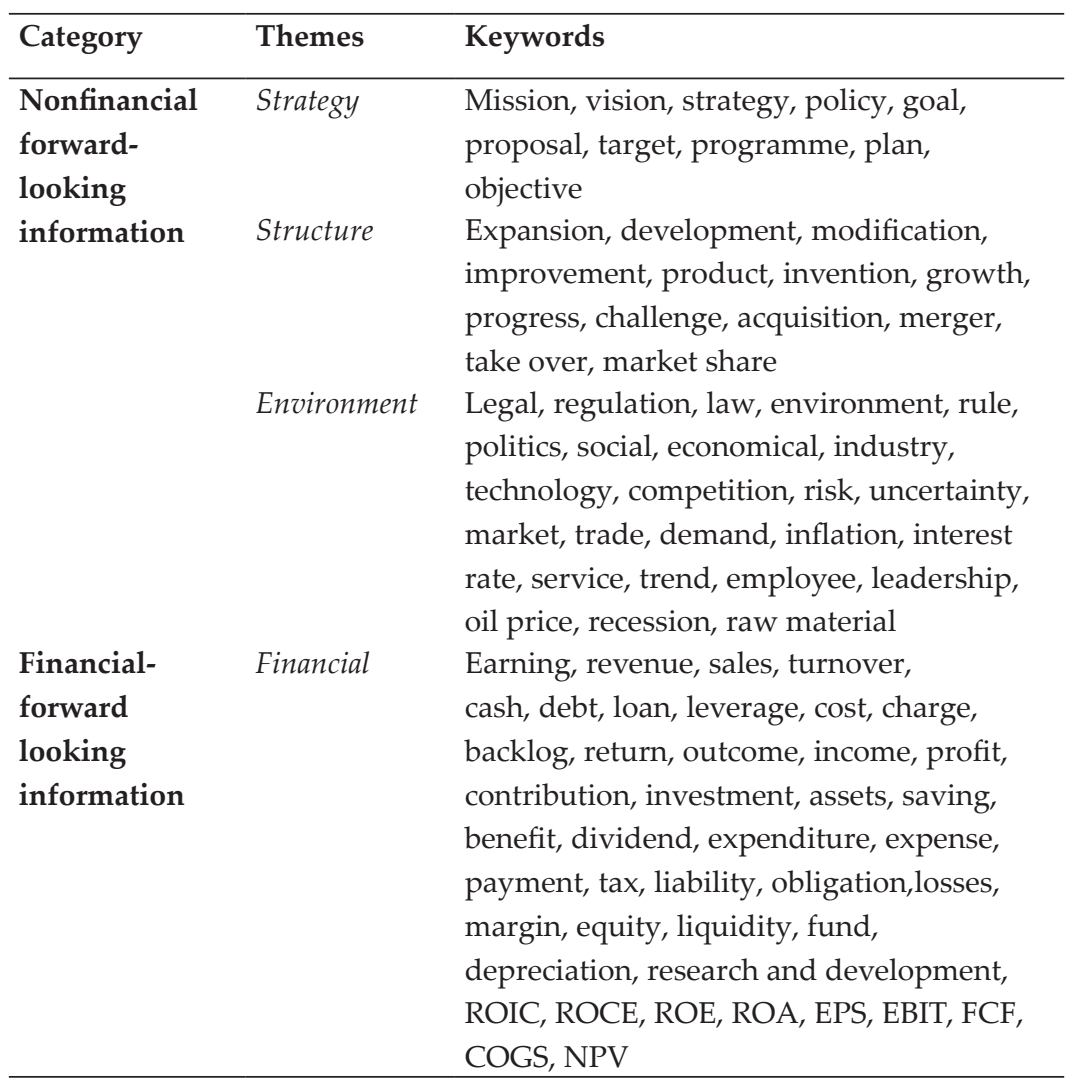

